\title{
2015, 2017 ve 2018 Hayat Bilgisi Dersi Öğretim Programları
}

\author{
Sayım AKTAY, Halise Sibel ÇETIN *
}

2015, 2017 ve 2018 Hayat Bilgisi Dersi Öğretim Prog-
ramları

Özet

Bu araştırmanın amacı 2015, 2017 ve 2018 Hayat Bilgisi dersi öğretim programlarını programın yapısı ve ögeleri açısından incelemektir. Çalışma nitel araştırma türünde olup veriler doküman analizi tekniği ile elde edilmiştir. Hayat Bilgisi dersi öğretim programları; programın ögeleri, program yapısı, öğretim programının amaçları, beceriler, değerler, ölçme ve değerlendirme, uygulamada dikkat edilecek hususlar, üniteler açısından değerlendirilmiştir. Araştırmanın bulgularına göre her üç program amaçlara, becerilere, değerlere ve ölçme ve değerlendirme anlayışına sahiptir. Ayrıca her üç programda 6 ünite yer almaktadır. 2017 ve 2018 programlarında yer alan üniteler aynı olup 2015 programı ile farklılık göstermektedir. 2015 programı sonrası programda ders koduna da yer verilmiştir. Ancak programın amaçlarında ve yer verilen değerlerde sadeleştirmeye gidildiği, becerilerin ise genel olarak aynı kaldığı ortaya çıkmıştır.

\author{
2015, 2017 and 2018 Life Sciences Course Teaching \\ Programs \\ Abstract
}

The aim of this research is to examine the curriculum of 2015, 2017 and 2018 Life Science course in terms of structure and elements of the program. The study is a qualitative research, and the data is obtained by document analysis technique. The elements of the program, program structure, objectives of the curriculum, skills, values, measurement and evaluation, the points to be considered in the application, and the units of Life Science course curriculum were evaluated. According to the findings of the study, all three programs have objectives, skills, values and understanding of assessment and evaluation. There are also 6 units in each of the three programs. The units included in the programs of 2017 and 2018 are the same but a little different from the 2015 program. The course code is included in the program after 2015 program. However, the programs aims and values were simplified and skills remained the same in general.

Key Words: Life Sciences Course, Life Sciences Teaching

Program, Primary School
Anahtar Kelimeler: Hayat Bilgisi Dersi, Hayat Bilgisi Dersi Öğretim Programı, illkokul

\section{Giriş}

Cumhuriyetin ilân edilmesiyle birlikte ülkemizde eğitim alanında hızlı bir şekilde gelişme olmuştur. Tüm öğretim kurumları 1924 yılında çıkarılan Tevhid-i Tedrisat Kanunu ile Millî Eğitim Bakanlığı çatısında toplanmış, okullarda uygulanan programlarda bazı değişik-

\footnotetext{
*Sayım AKTAY, Dr. Öğr.Üyesi, Muğla Sıtkı Koçman Üniversitesi Eğitim Fakültesi,Temel Eğitim Bölümü, sayimaktay@mu.edu.tr, ORCID ID orcid.org/0000-0002-5301-0099, Halise Sibel ÇETiN, Milli Eğitim Bakanlığı, sibelcetin1995@ gmail.com, ORCID ID orcid.org/0000-0002-0257-9947
} 
liklere gidilmiştir. Cumhuriyet dönemi boyunca birçok kez değişikliğe uğrayan ilköğretim programları kapsamında Hayat Bilgisi derslerinin eğitim programlarında da bu süreçte değişiklikler olmuştur (Kazu ve Aslan, 2012). İlkokulun ilk üç sınıfında mihver ders olan Hayat Bilgisi dersi çocuğa içinde bulunduğu doğal ve toplumsal çevreyi ve kendini tanımasına imkan sunmaktadır (Şahin, 2009). Bu derste öğrenciye okulda önce kendi özelliklerini, sonra arkadaşlarının özelliklerini tanıma fırsatı verilmektedir (Bektaş, 2007). Ayrıca bu ders ile çocuğun üst öğrenime hazırlanması ve toplumsal kimlik elde etmesi sağlanmaktadır (Aykaç, 2011). Hayat Bilgisi dersinde, öğrenciler okul ve sınıf kurallarını, toplumda yaşamanın kurallarını, bireylerin birbirlerine karşı saygılı, dürüst olmalarını, iş birliğini, yardımlaşmayı, sınıflarda yapılan seçimler ile demokrasiyi, öğrenirler. Gerçek hayat ile ilgili olan bu derste öğrenciler hayatta karşılaşabilecekleri sorunlara karşı çözüm yolları üretmeyi öğrenirler (Bahçe, 2010).

Hayat Bilgisi dersi bireylerin yaşamlarında elde edecekleri bilgilere temel oluşturacak bir derstir (Acat, Anılan, Girmen ve Anagün, 2005) Hayat Bilgisi dersi öğretim programında birey, psikolojik, biyolojik, sosyal ve kültürel yönleriyle öne çıkmaktadır (Öztürk, 2015). Hayat Bilgisi programları, yapılandırmacı eğitim anlayışına göre geliştirilmiştir (Güven, 2010). Hayat Bilgisi eğitim programının uygulanmasında bilinenden bilinmeyene, basitten karmaşığa, kolaydan zora, somuttan soyuta ilkeleri göz önünde bulundurulmalıdır. Derste grup çalışmaları, rol yapma, oyun, drama gibi tekniklere ağırlık verilmelidir. Konuların programda verilen sırada islenme zorunluluğu bulunmamaktadır. Öğretmen ders işlerken yol gösterici olmalı, öğrencinin derse katılımını ve yaparak yaşayarak öğrenmesini sağlamalıdır (Şahin, 2009). Hayat Bilgisi dersi öğrencilerin günlük yaşam içerisinde gereksinim duydukları temel bilgi ve becerilere sahip bireyler olmasını sağlamaktadır (Sönmez, 1997). Dolayısıyla, Hayat Bilgisi dersi, çocukların yaşama uygun öğrenmeler yoluyla yaşam becerileri kazanmasına olanak tanımaktadır (Öztürk ve Kalafatçı, 2016). Derslerin içeriklerinin ve sahip olduğu hedeflerin gerçekleştirilebilmesi bağlamında en önemli etkenlerden birinin eğitim programları olduğu (Akyürek Tay ve Baş, 2017) düşünüldüğünde, Hayat Bilgisi dersi öğretim programının niteliği önem arz etmektedir.

Alanyazın incelendiğinde, Hayat Bilgisi dersi öğretim programında verilen kazanımların günlük yaşamla bağlantılı olması ve öğrencinin kendisini tanımasını sağlayarak öğrenciyi hayata hazırlaması açısından önem taşıdığı açıktır. Ayrıca hayat bilgisi dersi mihver ders olduğu için hem öğretmene hem de diğer derslere rehberlik etmektedir. Alanyazın incelendiğinde, daha önceki yıllarda yapılan Hayat Bilgisi dersi öğretim programları karşılaştırmalı olarak incelenirken, 2015, 2017 ve 2018 programlarının incelenmediği görülmektedir. Dolayısıyla, 2015, 2017 ve 2018 Hayat Bilgisi dersi öğretim programlarının karşılaştırmalı olarak incelenmesi hem Hayat Bilgisi programlarındaki gelişmelerin takibi hem de Hayat Bilgisi dersinin geliştirilmesi bağlamında önem arz etmektedir. Bu çalışmanın 
amacı, 2015, 2017 ve 2018 Hayat Bilgisi dersi öğretim programlarını programın yapısı ve ögeleri açısından incelemektir.

\section{Yöntem}

\subsection{Araştırmanın Deseni}

2015, 2017 ve 2018 Hayat Bilgisi dersi öğretim programlarını çeşitli değişkenler açısından incelemeyi amaçlayan bu araştırmada nitel araştırma modeli benimsenmiştir. Nitel araştırma (Tavşancıl ve Aslan, 2001; Yıldırım ve Şimşek, 2006), algıların ve olayların doğal ortamda gerçekçi ve bütüncül bir biçimde ortaya konmasına yönelik nitel bir sürecin izlendiği araştırma yöntemidir.

Hayat Bilgisi programlarını çeşitli değişkenler açısından incelemeyi amaçlayan bu araştırmada veri toplama aracı olarak doküman analizi tekniği kullanılmıştır. Dergi, günlük, öğrenci ve öğretmen kayıtları gibi dokümanları analiz etmeye olanak tanıyan doküman analizi kesin bir doğruluk sağlamaktadır (Grady, 1998). Hayat Bilgisi programlarının incelenmesi bağlamında en uygun teknik olarak görüldüğü için doküman analizi tercih edilmiştir. Araştırmada incelenecek programlarda ölçüt olarak Milli Eğitim Bakanlığı tarafından oluşturulmuş olan son üç Hayat Bilgisi dersi öğretim programı ele alınmıştır. Dolayısıyla, araştırmada doküman analizi bağlamında veri kaynağı olarak 2015, 2017 ve 2018 Hayat Bilgisi dersi öğretim programları kullanılmıştır. Ayrıca, araştırmadaki veri toplama süreci, kaynakların nasıl seçildiği ve analiz edildiği araştırma bağlamında sunulmuş ve yapılan araştırmanın transfer edilebilirliği (Creswell \& Miller, 2000) arttırılmaya çalışılmıştır

Verilerin analiz edilmesi bağlamında gerek alanyazın gerekse programlar incelenerek kıstaslar oluşturulmuştur. Programların incelenmesinde ve karşılaştırılmasında kullanılan ölçütler programın yapısı, programın öğeleri, amaçları, beceriler, değerler, ölçme ve değerlendirme, dikkat edilecek hususlar ile ünitelerdir. 2015, 2017 ve 2018 Hayat Bilgisi dersi öğretim programları belirlenmiş olan bu ölçütlere göre sıralı bir yapı içinde incelenerek raporlaştırılmıştır. 
Sayım AKTAY | Halise Sibel ÇETIN

\section{Bulgular ve Yorumlar}

Araştırmanın bulguları, araştırmanın amaçları doğrultusunda sistematik bir biçimde aşağıda verilmeye sunulmuştur.

\subsection{Programların yapısı}

Tablo 2. 2015, 2017 ve 2018 Hayat Bilgisi Programlarının Yapısı

\begin{tabular}{lll}
\hline \hline \multicolumn{1}{c}{2015} & \multicolumn{1}{c}{2017} & \multicolumn{1}{c}{2018} \\
\hline Sınıf düzeyi & Dersin kodu & Dersin kodu \\
Ünite numarası & Sınıf düzeyi & Sınıf düzeyi \\
Kazanım numarası & Ünite numarası & Ünite numarası \\
& Kazanım numarası & Kazanım numarası \\
\hline
\end{tabular}

2015, 2017 ve 2018 Hayat Bilgisi programlarının yapısı incelendiğinde, 2015 programının sınıf düzeyi, ünite numarası ve kazanım numarası esas alınarak düzenlendiği görülmektedir. Ancak 2017 ve 2018 programlarında dersin kodunun da yer aldığı görülmüştür.

\subsection{Programların ögeleri}

Tablo 1. 2015, 2017 ve 2018 Hayat Bilgisi Programlarının Ögeleri

\begin{tabular}{lll}
\hline \hline 2015 & 2017 & 2018 \\
\hline
\end{tabular}

Hayat Bilgisi dersi öğretim prog- Öğretim programının te- Milli Eğitim Bakanlığı ramın amaçları mel felsefesi öğretim programları

Hayat Bilgisi dersi öğretim programı beceri ve değerleri

Öğretim programının genel amaçları
Öğretim programlarının amaçları 
Hayat Bilgisi dersi öğretim programın programının organizasyon yapısı
Öğretim programında Öğretim programlatemel beceriler

rının perspektifi

Değerlerimiz

Yetkinlikler
Hayat Bilgisi dersi öğretim programın uygulanmasına ilişkin açıklamalar

Illkokul 1.sınıf Hayat Bilgisi dersi öğretim programı

Ilkokul 2.sınıf Hayat Bilgisi dersi öğretim programı

Illkokul 3.sınıf Hayat Bilgisi dersi öğretim programı
Öğretim programında Öğretim programladeğerler eğitimi rında ölçme ve değerlendirme yaklaşımı

Öğretim programında Bireysel gelişim ve ölçme ve değerlendirme öğretim programları yaklaşımı

Öğretim programında Hayat Bilgisi dersi rehberlik öğretim programının özel amaçları

Hayat Bilgisi dersi öğretim programının becerileri
Öğretim programının yapıSI
Hayat Bilgisi dersi öğretim programının uygulanmasında dikkat edilecek hususlar

1.sınıf kazanım ve açıklamaları

Hayat Bilgisi dersi öğretim programının yapısı

2.sınıf kazanım ve açıkla- Hayat Bilgisi dersi 1, maları
2 ve 3. sınıflar ders kitabı forma sayıları 
ve ebatları

$\begin{aligned} & \text { 3.sınıf kazanım ve açıkla- } \\ & \text { maları }\end{aligned}$
açıklamaları
$\begin{aligned} & \text { 2.sınıf kazanım ve } \\ & \text { açıklamaları }\end{aligned}$
3.sınıf kazanım ve
açıklamaları

2015, 2017 ve 2018 öğretim programları ögeleri açısından incelendiğinde her üç programda amaçlar, ölçme ve değerlendirme yaklaşımına yer verilmiştir. 2015 programında illkokul 1. sınıf Hayat Bilgisi dersi öğretim programı, illkokul 2. sınıf Hayat Bilgisi dersi öğretim programı, illkokul 3. sınıf Hayat Bilgisi dersi öğretim programı başlıkları yer alırken 2017 ve 2018 programlarında 1. sınıf kazanım ve açıklamaları, 2. sınıf kazanım ve açıklamaları, 3. sınıf kazanım ve açıklamaları başlığı bulunmaktadır. 2015 ve 2018 programlarında programın yapısı yer alırken 2017 programında bu ögeye yer verilmemiştir. Ayrıca 2015 programında Hayat Bilgisi dersi öğretim programı beceri ve değerleri, Hayat Bilgisi dersi öğretim programın uygulanmasına ilişkin açıklamalar başlığı; 2017 programında ise öğretim programının temel felsefesi, öğretim programında temel beceriler, öğretim programında değerler eğitimi, öğretim programında rehberlik, öğretim programının uygulanmasında dikkat edilecek hususlar yer almaktadır. Milli Eğitim Bakanlığı öğretim programları, öğretim programlarının perspektifi, bireysel gelişim ve öğretim programları, Hayat Bilgisi dersi öğretim programının özel amaçları, Hayat Bilgisi dersi 1, 2 ve 3. sınıflar ders kitabı forma sayıları ve ebatları 2015 ve 2017 programlarında yer almazken sadece 2018 programında yer almaktadır. Ayrıca 2017 ve 2018 programında Hayat Bilgisi dersi öğretim programının uygulanmasında dikkat edilecek hususlar ögeleri bulunmaktadir. 


\subsection{Programların amaçları}

Tablo 3. 2015, 2017 ve 2018 Hayat Bilgisi Programlarında Amaçlar

Okulu ve okul içindeki ilişkileri tanımasını,

Grupla çalışma, akranlarıyla iş birliği yapma ve sosyal katılım becerilerini geliştirmesini,

Fiziksel ve kişisel özellikleri ile kendini tanımasını,

Aileye ve aile içi ilişkilere dair bir anlayış geliştirerek aile ile ilgili temel değerleri içselleştirmesini,

Kişisel bakım becerilerini geliştirmesini,

Kaynakları verimli kullanma becerilerini geliştirmesini,

Zamanı algılama ve etkili kullanma becerilerini geliştirmesini,

Sağlıklı ve dengeli beslenme becerilerini ve alışkanlıklarını geliştirmesini,

Evde, okulda ve okulun dışında kişisel güvenliğini sağlama becerilerini geliştirmesini,

Bilişim teknolojilerini bilinçli ve güvenli kullanım becerilerini geliştirmesini,

Millî, manevi ve insani değerleri içselleştirmesini,
Temel yaşam becerilerine sahip,

Kendini tanıyan,

Sağlıklı ve güvenli bir yaşam süren,

Yaşadığı toplumun değerlerini özümseyen,

Doğaya ve çevreye duyarlı,

Araştıran, üreten ve ülkesini seven bireyler yetiştirmektir. 
Düşünme, sorgulama, farklı düşünceler ve çözümler üretme becerilerini geliştirmesini,

Doğayı ve çevreyi temiz tutma ve koruma becerilerini geliştirmesini,

Doğa ile ilgili sorular sorabilme, gözlem yapabilme, gözlem sonuçlarını gruplama, sınıflama ve karşılaştırma yoluyla bilimsel bir anlayış geliştirmesini sağlamaktır.

2015, 2017 ve 2018 Hayat Bilgisi dersi öğretim programları incelendiğinde üç programda da amaçların yer aldığı ancak 2015 Hayat Bilgisi dersi öğretim programında daha ayrıntılı verildiği görülmektedir. Ayrıca 2017 ve 2018 Hayat Bilgisi dersi öğretim programIarının amaçlarının aynı olduğu belirlenmiştir. Dolayısıyla programın amaçlarında bir sadeleştirme olduğu göze çarpmaktadır. 
Eskişehir Osmangazi Üniversitesi Sosyal Bilimler Dergisi

\subsection{Programlardaki beceriler}

Tablo 4. 2015, 2017 ve 2018 Hayat Bilgisi Programlarında Beceriler

\begin{tabular}{|c|c|c|}
\hline 2015 & 2017 & 2018 \\
\hline Araştırma & Araştırma & Araştırma \\
\hline $\begin{array}{l}\text { Bilgi ve iletişim teknolojilerini kul- } \\
\text { lanma }\end{array}$ & $\begin{array}{l}\text { Bilgi ve iletişim teknolojilerini } \\
\text { kullanma }\end{array}$ & $\begin{array}{l}\text { Bilgi ve iletişim } \\
\text { teknolojilerini } \\
\text { kullanma }\end{array}$ \\
\hline Değişim ve sürekliliği algılama & Değişim ve sürekliliği algılama & $\begin{array}{l}\text { Değişim ve sü- } \\
\text { rekliliği algılama }\end{array}$ \\
\hline Dengeli beslenme & Dengeli beslenme & $\begin{array}{l}\text { Dengeli beslen- } \\
\text { me }\end{array}$ \\
\hline Doğayı koruma & Doğayı koruma & Doğayı koruma \\
\hline Girişimcilik & Girişimcilik & Girişimcilik \\
\hline Gözlem & Gözlem & Gözlem \\
\hline İletişim & İletişim & İletişim \\
\hline İş birliği & İş birliği & İş birliği \\
\hline Karar verme & Karar verme & Karar verme \\
\hline Kaynakların kullanımı & Kaynakların kullanımı & $\begin{array}{l}\text { Kaynakların } \\
\text { kullanımı }\end{array}$ \\
\hline Kendini koruma & Kendini koruma & Kendini koruma \\
\hline
\end{tabular}


Sayım AKTAY | Halise Sibel ÇETIN

\begin{tabular}{|c|c|c|}
\hline Kendini tanıma & Kendini tanıma & Kendini tanıma \\
\hline Kişisel bakım & Kişisel bakım & Kişisel bakım \\
\hline Kurallara uyma & Kurallara uyma & Kurallara uyma \\
\hline Mekânı algılama & Mekânı algılama & Mekânı algılama \\
\hline Millî ve kültürel değerleri tanıma & Millî ve kültürel değerleri tanıma & $\begin{array}{l}\text { Millî ve kültürel } \\
\text { değerleri tanıma }\end{array}$ \\
\hline Öz yönetim & Öz yönetim & Öz yönetim \\
\hline Sağlığını koruma & Sağlığını koruma & Sağ|ığını koruma \\
\hline Sorun çözme & Sorun çözme & Sorun çözme \\
\hline Sosyal katılım & Sosyal katılım & Sosyal katılım \\
\hline \multirow[t]{3}{*}{ Zaman yönetimi } & Zaman yönetimi & Zaman yönetimi \\
\hline & Kariyer bilinci geliştirme & $\begin{array}{l}\text { Kariyer bilinci } \\
\text { geliştirme }\end{array}$ \\
\hline & \multicolumn{2}{|l|}{ Sorumluluk bilinci } \\
\hline $\begin{array}{l}\text { 2015, } 2017 \text { ve } 2018 \text { Hayat B } \\
\text { lendiğinde } 2015 \text { programında } 22 \\
\text { yer almaktadır. Bu programlarda } \\
\text { programına ek olarak kariyer bili } \\
\text { ramında sorumluluk bilinci becer } \\
\text { nan becerilerin genel olarak aynı }\end{array}$ & $\begin{array}{l}\text { dersi öğretim programları bece } \\
17 \text { programında } 24,2018 \text { progra } \\
\text { eriler aynı olup } 2017 \text { ve } 2018 \text { p } \\
\text { seliştirme becerisi yer almaktadı } \\
\text { ulunmaktadır. Dolayısıyla ilgili pr } \\
\text { ı̆̆ söylenebilir. }\end{array}$ & $\begin{array}{l}\text { er açısından ince- } \\
\text { ında ise } 23 \text { beceri } \\
\text { gramlarında } 2015 \\
\text { Ayrıca } 2017 \text { prog- } \\
\text { ramlarda amaçla- }\end{array}$ \\
\hline
\end{tabular}


Eskişehir Osmangazi Üniversitesi Sosyal Bilimler Dergisi

\subsection{Programlardaki değerler}

Tablo 5. 2015, 2017 ve 2018 Hayat Bilgisi Programlarında Değerler

\begin{tabular}{|c|c|c|}
\hline 2015 & 2017 & 2018 \\
\hline Adalet & Adalet & Adalet \\
\hline Bilimsellik & Aile birliğine önem verme & Dostluk \\
\hline Çalışkanlık & Bağımsızlık & Dürüstlük \\
\hline Dayanışma & Bilimsellik & Öz denetim \\
\hline Doğa sevgisi & Çalışkanlık & Sabır \\
\hline Doğruluk & Dayanışma & Saygı \\
\hline Dürüstlük & Duyarlılık & Sevgi \\
\hline Estetik & Doğruluk & Sorumluluk \\
\hline Güven & Dostluk & Vatanseverlik \\
\hline Hoşgörü & Dürüstlük & Yardımseverlik \\
\hline Merhamet & Estetik & \\
\hline Misafirperverlik & Güven & \\
\hline Öz güven & Merhamet & \\
\hline Paylaşma & Misafirperverlik & \\
\hline
\end{tabular}


Sayım AKTAY | Halise Sibel ÇETIN

\begin{tabular}{cc}
\hline Sabır & Paylaşma \\
Saygı & Sabır \\
Sevgi & Saygı \\
Sorumluluk & Sevgi \\
Vatanseverlik & Sorumluluk \\
Yardımlaşma & Vatanseverlik \\
& \\
& Vefa \\
\hline \hline
\end{tabular}

2015, 2017 ve 2018 Hayat Bilgisi dersi öğretim programlarında değerlere yer verilmiştir. 2015 programında 20, 2017 programında 22, 2018 programında ise 10 değere yer verilmiştir. Ayrıca 2018 programında yer alan değerler kök değerler olarak belirtilmiştir. Dolayısıyla, 2018 programında birçok değer vermek yerine temel değerlere odaklanıldığı söylenebilir. 


\subsection{Programlarda ölçme ve değerlendirme}

Tablo 6. 2015, 2017 ve 2018 Hayat Bilgisi Programlarında Ölçme ve Değerlendirme

\begin{tabular}{ccc}
\hline \hline 2015 & 2017 & 2018 \\
\hline Süreç odaklı & Tanıma & $\begin{array}{c}\text { Çok odaklı̈lçme ve } \\
\text { değerlendirme }\end{array}$ \\
& İzleme-biçimlendirme & \\
Sonuç (ürün)
\end{tabular}

2015 Hayat Bilgisi dersi öğretim programında süreç odaklı ölçme ve değerlendirme esas iken 2017 programında tanıma, izleme ve sonuç odaklı olmak üzere üç farklı şekilde yapılmaktadır. 2018 programında ise çok odaklı ölçme ve değerlendirme yapılmakta ve süreç içerisindeki değişimler dikkate alınmaktadır.

\subsection{Programlarda dikkat edilecek hususlar}

Tablo 7. 2015, 2017 ve 2018 Hayat Bilgisi Programlarında Dikkat Edilecek Hususlar

1, 2 ve 3. sınıflar öğretim programı uygulanırken öğretmenlerin sınıf içi ve sınıf dışı uygulamalar yapmaları gerekmektedir.

Sınıf içi uygulamalarda öğretmenler; öğrencilerin bilişsel, duyuşsal ve devinişsel gelişimleri ile bireysel farklııklarını dikkate almalıdır.

Öğretmen, sınıfta dersi işlerken öğrencilerin önceki yaşantılarından hareket ederek konular arasında bağlantı kur-
Dersin işlenişinde okul içi ve okul dışı uygulamalar yapmaya özen gösterilmelidir.

Okul içi ve okul dışı uygulamalarda öğrencilerin bilişsel, duyuşsal ve devinişsel gelişimleri ile bireysel farklılıkları dikkate alınmalıdır.

Kazanımlar doğrultusunda yapılacak etkinliklerle okul ve yaşam arasında bağlantı kurulmasına özen gösterilmelidir. 


\section{Sayım AKTAY | Halise Sibel ÇETIN}

malıdır.

Öğretmen, sınıf ortamında kazanımlara uygun öğretim yapmalı, ürün odaklı ölçme değerlendirme yöntemlerini kullanmanın yanı sıra süreç odaklı ölçme değerlendirme yöntemlerini kullanmaya önem vermelidir.

Öğretmen, sınıf dışı uygulamalar gerçekleştirirken yakın çevreye geziler düzenlemeli ve bu gezilerde önceden planlanan etkinlikleri yaptırmalıdır.

Öğretmen, öğretim programında yer alan bazı kazanımları belirli gün ve haftalara denk gelen zaman dilimlerinde işlemelidir.

Üçüncü sınıfa kadar millî bayramlar vb. konular işlenirken öğrenciler henüz 1000 'den büyük sayıları okumayı ve yazmayı öğrenmedikleri için ders kitabında tarihler rakam veya yazı ile verilmemelidir.
Öğrencilerin çevrelerinde bulunan canlı ve cansız varlıkları etik konulara dikkat ederek öğretim materyali olarak kullanmalarına imkân tanınmalıdır.

Özellikle öğrencilerin araştırma yapmaları beklenen çalışmalarda, araştırma sonuçlarını afiş, poster, pano, broşür, gazete, tablo, grafik vb. materyaller kullanarak sınıfta arkadaşları ile paylaşması desteklenmelidir.

Doğa içerikli kazanımlarda basit düzeyde deneyler yaptırılabilir.

Öğretim Programı'nda yer alan bazı kazanımlar, belirli gün ve haftalara denk gelen zaman dilimlerinde işlenmelidir.

Üçüncü sınıfa kadar millî bayramlar vb. konular işlenirken öğrenciler henüz 1000 'den büyük sayıları okumayı ve yazmayı öğrenmedikleri için ders kitabında tarihler rakam veya yazı ile verilmemelidir.

Program uygulanırken özel gereksinimi olan öğrenciler için gereken esneklik gösterilmeli, öğrencilerin ilgi, istek ve ihtiyaçları doğrultusunda etkinlikler hazırlanmalı ve planlamalar yapılmalıdır.

Program uygulanırken öğrencilerin değerleri kazanmasına özen gösterilmeli, tüm kazanımlar ilgili değerlerle eşleştirilmeli ve örtük program anlayışından hareketle dersler işlenmelidir.

Öğrencilerin gelişim düzeylerine uygun olarak, kazanımlar için gerekli temel ya- 
şam becerilerinin geliştirilmesine önem verilmeli ve etkinlikler bu anlayışla hazırlanmalıdır.

2015, 2017 ve 2018 Hayat Bilgisi dersi öğretim programları dikkat edilecek hususlar açısından incelendiğinde 2015 programında 7, 2017 ve 2018 öğretim programlarında ise 11 madde yer almaktadır. 2017 ve 2018 programlarına özel gereksinimi olan öğrenciler için esneklik gösterilmesi, öğrencilerin değerleri kazanması, temel yaşam becerilerin geliştirilmesi gibi boyutlarda maddeler eklenmiştir.

\subsection{Programlardaki üniteler}

Tablo 8. 2015, 2017 ve 2018 Hayat Bilgisi programlarında üniteler

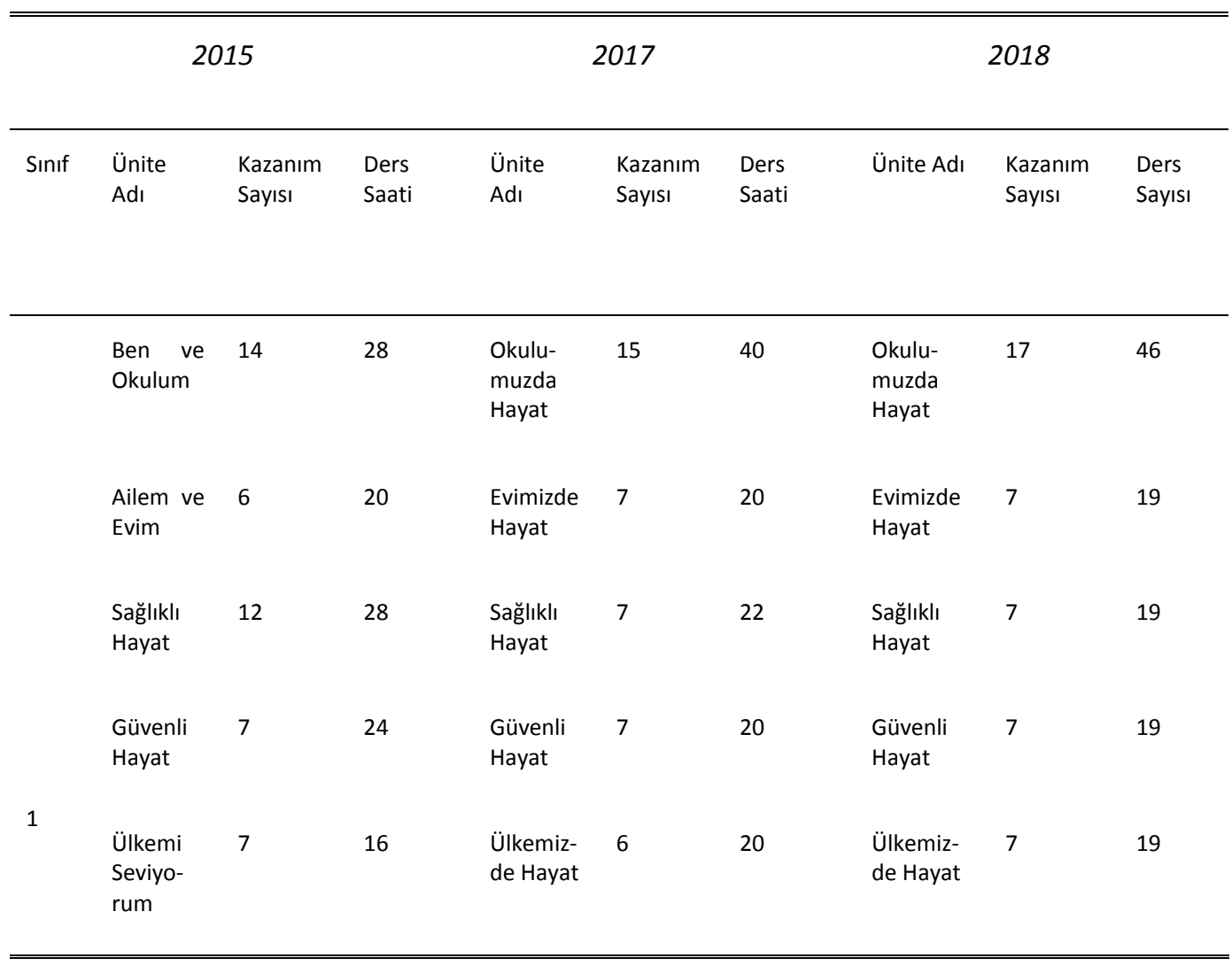


Sayım AKTAY | Halise Sibel ÇETIN

\begin{tabular}{|c|c|c|c|c|c|c|c|c|}
\hline $\begin{array}{l}\text { Doğa ve } \\
\text { Çevre }\end{array}$ & 8 & 28 & $\begin{array}{l}\text { Doğada } \\
\text { Hayat }\end{array}$ & 8 & 22 & $\begin{array}{l}\text { Doğada } \\
\text { Hayat }\end{array}$ & 8 & 22 \\
\hline TOPLAM & 54 & 144 & TOPLAM & 50 & 144 & TOPLAM & 53 & 144 \\
\hline $\begin{array}{l}\text { Ben ve } \\
\text { Okulum }\end{array}$ & 11 & 24 & $\begin{array}{l}\text { Okulu- } \\
\text { muzda } \\
\text { Hayat }\end{array}$ & 11 & 30 & $\begin{array}{l}\text { Okulu- } \\
\text { muzda } \\
\text { Hayat }\end{array}$ & 11 & 32 \\
\hline $\begin{array}{l}\text { Ailem } \\
\text { Evim }\end{array}$ & 6 & 20 & $\begin{array}{l}\text { Evimizde } \\
\text { Hayat }\end{array}$ & 9 & 28 & $\begin{array}{l}\text { Evimizde } \\
\text { Hayat }\end{array}$ & 9 & 26 \\
\hline $\begin{array}{l}\text { Sağlıklı } \\
\text { Hayat }\end{array}$ & 7 & 28 & $\begin{array}{l}\text { Sağlıklı } \\
\text { Hayat }\end{array}$ & 7 & 22 & $\begin{array}{l}\text { Sağlıklı } \\
\text { Hayat }\end{array}$ & 7 & 20 \\
\hline $\begin{array}{l}\text { Güvenli } \\
\text { Hayat }\end{array}$ & 8 & 28 & $\begin{array}{l}\text { Güvenli } \\
\text { Hayat }\end{array}$ & 6 & 20 & $\begin{array}{l}\text { Güvenli } \\
\text { Hayat }\end{array}$ & 6 & 17 \\
\hline $\begin{array}{l}\text { Ülkemi } \\
\text { Seviyorum }\end{array}$ & 7 & 16 & $\begin{array}{l}\text { Ülkemiz- } \\
\text { de Hayat }\end{array}$ & 8 & 20 & $\begin{array}{l}\text { Ülkemiz- } \\
\text { de Hayat }\end{array}$ & 8 & 23 \\
\hline $\begin{array}{l}\text { Doğa } \\
\text { Çevre }\end{array}$ & 10 & 28 & $\begin{array}{l}\text { Doğada } \\
\text { Hayat }\end{array}$ & 9 & 24 & $\begin{array}{l}\text { Doğada } \\
\text { Hayat }\end{array}$ & 9 & 26 \\
\hline TOPLAM & 49 & 144 & TOPLAM & 50 & 144 & TOPLAM & 50 & 144 \\
\hline $\begin{array}{l}\text { Ben ve } \\
\text { Okulum }\end{array}$ & 6 & 20 & $\begin{array}{l}\text { Okulu- } \\
\text { muzda } \\
\text { Hayat }\end{array}$ & 9 & 24 & $\begin{array}{l}\text { Okulu- } \\
\text { muzda } \\
\text { Hayat }\end{array}$ & 10 & 24 \\
\hline $\begin{array}{l}\text { Ailem ve } \\
\text { Evim }\end{array}$ & 6 & 14 & $\begin{array}{l}\text { Evimizde } \\
\text { Hayat }\end{array}$ & 8 & 20 & $\begin{array}{l}\text { Evimizde } \\
\text { Hayat }\end{array}$ & 8 & 19 \\
\hline $\begin{array}{l}\text { Sağlıklı } \\
\text { Hayat }\end{array}$ & 5 & 16 & $\begin{array}{l}\text { Sağlıklı } \\
\text { Hayat }\end{array}$ & 5 & 13 & $\begin{array}{l}\text { Sağlıklı } \\
\text { Hayat }\end{array}$ & 5 & 12 \\
\hline $\begin{array}{l}\text { Güvenli } \\
\text { Hayat }\end{array}$ & 10 & 24 & $\begin{array}{l}\text { Güvenli } \\
\text { Hayat }\end{array}$ & 6 & 15 & $\begin{array}{l}\text { Güvenli } \\
\text { Hayat }\end{array}$ & 7 & 17 \\
\hline
\end{tabular}


Eskişehir Osmangazi Üniversitesi Sosyal Bilimler Dergisi

\begin{tabular}{|c|c|c|c|c|c|c|c|c|c|c|}
\hline \multirow[t]{2}{*}{3} & $\begin{array}{l}\text { Ülkem } \\
\text { Seviyo }\end{array}$ & & 9 & 16 & $\begin{array}{l}\text { Ülkemiz- } \\
\text { de Hayat }\end{array}$ & 9 & 22 & $\begin{array}{l}\text { Ülkemiz- } \\
\text { de Hayat }\end{array}$ & 9 & 22 \\
\hline & $\begin{array}{l}\text { Doğa } \\
\text { çevre }\end{array}$ & ve & 7 & 18 & $\begin{array}{l}\text { Doğada } \\
\text { Hayat }\end{array}$ & 6 & 14 & $\begin{array}{l}\text { Doğada } \\
\text { Hayat }\end{array}$ & 6 & 14 \\
\hline \multicolumn{3}{|c|}{ TOPLAM } & 43 & 108 & TOPLAM & 43 & 108 & TOPLAM & 45 & 108 \\
\hline
\end{tabular}

2015, 2017 ve 2018 programları incelendiğinde, 1. ve 2. sınıflarda toplam ders saati 144 iken 3. Sınıflarda 108 saattir. 2015, 2017 ve 2018 Hayat Bilgisi dersi öğretim programlarında 6 ünite yer almaktadır. 2017 ve 2018 programlarında yer alan üniteler aynı olup 2015 programı ile farklılık göstermektedir.

\section{Sonuç ve Öneriler}

Araştırma bulguları incelendiğinde 2015, 2017 ve 2018 Hayat Bilgisi dersi öğretim programlarının üçünde de amaçlar, beceriler, değerler ve dikkat edilecek hususlar yer almaktadır. Ayrıca, her üç programda amaçlar, ölçme ve değerlendirme yaklaşımına yer verilmiş ve programlarının yapısı sınıf düzeyi, ünite numarası ve kazanım numarası esas alınarak düzenlenmiştir. Bunun yanı sıra, 2015 programı sonrası programda ders koduna da yer verilmiştir. Ancak programın amaçlarında ve yer verilen değerlerde sadeleştirmeye gidildiği görülmektedir. Programdaki beceriler ise genel olarak aynı kalmıştır. Ölçme ve değerlendirme açısından programlar incelendiğinde ise 2015 Hayat Bilgisi dersi öğretim programında süreç odaklı ölçme ve değerlendirme esas iken 2017 programında tanıma, izleme ve sonuç odaklı ölçme ve değerlendirme olmak üzere üç farklı şekilde yapılmaktadır. 2018 programında ise çok odaklı ölçme ve değerlendirme yapılmakta ve süreç içerisindeki değişimler dikkate alınmaktadır. Ayrıca her üç programda da altı ünite yer almaktadır.

Alanyazın incelendiğinde, önceki yıllarda oluşturulan Hayat Bilgisi dersi öğretim programlarının bazı araştırmacılar tarafından farklı özellikler bakımından ya da karşılıklı olarak incelendiği görülmektedir. Özçetin (2000) 3. Sınıf öğretmenlerinin görüşleri ile 1998 hayat bilgisi öğretim programını incelediğinde programın değerlendirme boyutu bakımından sınırlı olduğu bulunmuştur. Acat ve Uzunkol (2007), Hayat Bilgisi dersi öğretim programı bağlamında öğretmenlerin kaynak sıkıntısı, kalabalık sınıflar ve süre yetersizliği gibi sorunlar üzerinde durduğunu bulmuştur. 
2005 yılı öğretim programlarının incelendiği bir araştırma raporunda (ERG, 2005), Hayat Bilgisi dersinin diğer derslerle ilişkisi incelendiğinde birinci sınıfta Türkçe dersi ile \%20 civarında, Matematik dersi ile \%4 civarında bir ilişki olduğu görülmüştür. Ayrıca, Yıldırım'ın (2006) araştırmasında, ilköğretim programları incelendiğinde, öğrenme-öğretme sürecinde öğretmenin rehberlik rolünün daha fazla ön plana çıktığı görülmüştür. Uğur (2006) tarafından gerçekleştirilen bir çalışmada da, 2005 yılında, 1998 programında uygulanan davranış̧̧ı yaklaşımın terk edilerek, öğreneni merkeze alan yapılandırmacı yaklaşımın benimsendiği görülmüştür. Ayrıca, yeni programın ilkokul öğretmenlerince 1998 programından daha iyi olduğu ortaya çıkmıştır. Narin (2007) tarafından yapılan bir diğer araştırmaya göre, öğretmenler 2005 Hayat Bilgisi dersi Öğretim Programının takım çalışması, iletişim ve iş birliği gibi birtakım sosyal becerileri geliştirdiğini düşünmektedir. Öztürk tarafından gerçekleştirilen bir diğer çalışmada ise, sınıf öğretmenlerinin, öğrencilerin iletişim ve temalarla ilgili temel kavramları iyi derecede, diğer becerileri ise orta derecede kazandıkları kanısında oldukları ortaya çıkmıştır. Gömleksiz ve Bulut (2007) yaptıkları bir çalışmada, programda öngörülen kazanımların uygulamada etkili olduğunu bulmuştur. Özden (2005), Hayat Bilgisi Öğretim Programını incelediğinde, Öğretmenlerin programda en çok ölçme değerlendirme bağlamında zorlandıkları görülmüştür.

Aykaç (2011), tarafından yapılan öğretmen görüşlerine dayalı çalışma sonucunda öğretmenlerin Hayat Bilgisi dersinde gezi-gözlem, inceleme gibi yaparak yaşayarak öğrenmeye dayalı yöntemlere yeterli miktarda yer verilmediği ifade edilmiştir. Yaşaroğlu (2013), tarafından yapılan bir diğer çalışmada ise Hayat Bilgisindeki kazanımlar değerler açısından incelenmiş olup bütün kazanımlarda en fazla sorumluluk değerine en az ise barış, şiddetsiz hayat ve ahlak değerlerine yer verildiği açıklanmıştır. Türkyılmaz (2011), Hayat Bilgisi dersi öğretim programını öğretmen görüşleri yoluyla incelemiş ve kazanımlar için sürenin yeterli olmaması, içeriklerin öğrencilerin ilgisini çekmemesi gibi sorunlara değinmiştir. Alak ve Nalçacı (2012), öğretmen görüşlerine göre kazanım, tema, etkinlikler ya da ölçme ve değerlendirme gibi Hayat Bilgisi dersi öğretim programı öğelerinin değerlendirilmesini yapmış ve araştırma sonucunda cinsiyet, meslekteki kıdem, mezun oldukları okul ve okuttukları sınıflardaki öğrenci mevcudu bakımından bir farklılık ortaya çıkmamıştır. Altun ve Çakmak (2013), tarafından yapılan çalışmada ise Hayat Bilgisi dersi öğretim programında medya okuryazarlığı eğitimi incelenmiştir. Araştırmada, medyanın sağlık davranışlarına etkisi, sağlık bilinci ve medyada şiddet temaları ile bilgi kaynağı olarak medya, medyanın etkileri, bir teknoloji olarak medya ve bilinçli tüketici temalarının ön planda olduğu ortaya çıkmıştır. 
Tay ve Baş (2015), tarafından yapılan çalışmada 2009 ve 2015 Hayat Bilgisi dersi öğretim programları; vizyon, program yaklaşımı, hedefler, içerik, eğitim durumları ve değerlendirme boyutları açısından incelenmiştir. Bu araştırmada, 2015 programında ünite temelli bir yaklaşım görülürken, 2009 programında çocuğu merkeze alan, toplu öğretim, tematik, spiral ve katılımcılık ilkelerine bağlı bir yaklaşım benimsendiği görülmüştür. Ayrıca, araştırma sonucunda 2009 programındaki kazanımların 2015 programında \%50 oranında azaltıldığı bulunmuştur. Gündoğan (2017), tarafından yapılan çalışmada ise 2015 Hayat Bilgisi dersi öğretim programı sosyal beceriler açısından ele alınmış olup programın genelinin sosyal beceriler kapsamında ilk kazandırılacak beceriler, duygulara yönelik beceriler, grupla bir işi yapma ve yürütme becerileri ile plan yapma ve problem çözme becerilerini kapsadığı ifade edilmiştir. Ayrıca, araştırmada programdaki amaçların \%50'sinin; becerilerin \%54'ünün ve değerlerin \%70'inin doğrudan ya da dolaylı olarak sosyal becerilerle bağlantılı olduğu görülmüştür. Ayrıca, programdaki kazanımların \%37'sinin sosyal beceri içerikli kazanımlar olduğu ortaya çıkmıştır. Demir (2016), tarafından gerçekleştirilen bir diğer araştırmada ise, öğretmen adaylarının yarıya yakın bir oranda Hayat Bilgisi Öğretim Programının değişmesi gerektiğini düşündükleri biçiminde ilginç bir araştırma bulgusuna ulaşılmıştır.

Uçuş Güldalı (2017) tarafından yapılan bir çalışmada 2009 ve 2017 Hayat Bilgisi dersi öğretim programları incelenerek karşılaştırılmıştır. Bu araştırma sonucunda, her iki programın vizyon, Türk Türk Milli Eğitim Amaçları, değerlendirme gibi boyutlar açısından benzerlikler taşıdığı; 2017 programında kazanım, değer, beceri ve Atatürkçülükle ilgili kazanım sayılarının azaldığı, ünite temelli yaklaşıma geçildiği, etkinlikler ile belirli gün ve haftalarla ilgili yeterince açıklama olmadığı görülmüştür. Çaycı (2017) tarafından yapılan bir diğer araştırmada, 2017 Hayat Bilgisi dersi öğretim programı öğretmen adayı görüşlerine göre incelenmiş, öğretmen adaylarının ilgili programın beceri ve değer kazandırma sürecinde gerekli ve yeterli yaklaşımları içermediği ve genel amaçlarla uyumluluk açısından bazı beceri ve değerlerin programa eklenmesi gerektiği yönünde görüş belirttikleri görülmüştür. Ayrıca, Karasu Avcı ve Ketenoğlu Kayabaşı (2018) tarafından gerçekleştirilen çalışmada 1936, 1948, 1968, 1998, 2005, 2009, 2015 ve 2018 Hayat Bilgisi dersi öğretim programlarının amaçlarındaki değerler ele alınmıştır. Araştırma sonucunda, 1936, 1948, 1968, 1998, 2005, 2009, 2015 ve 2018 Hayat Bilgisi derslerinin amaçlarında sevgi, saygı, duyarlılık, sorumluluk, doğruluk ve dürüstlük gibi değerlerin yer aldığı görülmüştür. 
Araştırma kapsamında elde edilen bulgular doğrultusunda aşağıdaki öneriler getirilmiştir:

- Daha önceki yıllardaki Hayat Bilgisi dersi öğretim programlarının da dahil edildiği geniş çaplı araştırmalar gerçekleştirilebilir.

- Hayat Bilgisi dersi öğretim programları farklı araştırma teknikleri ile incelenebilir.

- Hayat Bilgisi dersi öğretim programları farklı değişkenler açısından da detaylı olarak incelenebilir. 


\section{Kaynaklar}

Acat, B., Anılan, H., Girmen, P. ve Anagün, Ş. (2005). Öğretmen adaylarının ilköğretim hayat bilgisi programında yer alan becerilere sahip olma düzeylerine ilişkin görüşleri, eğitimde yansımalar VIII: Yeni İlköğretim Programlarının Değerlendirilmesi Sempozyumu,14-16 Kasım 2005 Erciyes Üniversitesi Eğitim Fakültesi, Kayseri. 394-405, Tekışık Eğitim Araştırma Vakfı Yayınları, Ankara.

Acat, B. ve Uzunkol, E. D. (2007). Sınıf Öğretmenlerinin İlköğretim Programlarındaki Değerlendirme Sürecine İlişkin Görüşleri. Elektronik Sosyal Bilimler Dergisi Kış-2010, 9(31), 001-027.

Akyürek Tay, B. ve Baş, M. (2017). Cumhuriyetten günümüze Hayat Bilgisi dersi öğretim programlarına karşılaştırmalı bir bakış. Tay, B., Uçuş Güldalı, ̧̧ ve Baş, M. (Ed.), Etkinlik örnekleriyle hayat bilgisi öğretimi. Ankara: Pegem A Akademi.

Alak, G. ve Nalçacı, A. (2012). Hayat Bilgisi dersi öğretim programı öğelerinin öğretmen görüşlerine göre değerlendirilmesi. Buca Eğitim Fakültesi Dergisi 33(2012), 36-51.

Altun, A. ve Çakmak, E. (2013). İlköğretim Hayat Bilgisi dersi öğretim programında medya okuryazarlığı eğitimi. Çankırı Karatekin Üniversitesi Sosyal Bilimler Enstitüsü Dergisi, 4(1), 237-254.

Aykaç, N. (2011). Hayat Bilgisi dersi öğretim programında kullanılan yöntem ve tekniklerin öğretmen görülerine göre değerlendirilmesi (Sinop ili örneği). Hayat, 19(1), 113126.

Bahçe, A. (2010). Hayat Bilgisi öğretiminde değerlerin kazandırılma düzeylerinin öğretmen görüşlerine göre değerlendirilmesi Yüksek lisans tezi. Selçuk Üniversitesi, Eğitim Bilimleri Enstitüsü. Konya.

Bektaş, M. (2007). Hayat Bilgisi dersinde ailelerin çoklu zekâ kuramı hakkında bilgilendirilme biçimlerinin öğrencilerin proje başarıları ve tutumlarına etkisi. Değerler Eğitimi Dergisi, 5(14), 9-28.

Çaycı, B. (2018). 2017 illkokul Hayat Bilgisi Dersi Öğretim Programının Öğretmen Adayı Görüşlerine Göre Değerlendirilmesi, International Journal Of Education Technology and Scientific Researches, 6, 74-98.

Creswell, J.W. ve Miller, D.L. (2000). Determining validity in qualitative inqury. Theory into Practice, 39: 124-130. 
Demir, M. K. (2016). Hayat Bilgisi dersi öğretim programının değiştirilmesi gerekçelerine dair öğretmen adayı görüşleri. The Journal of Academic Social Science Studies, (47), 157-171.

ERG. (2005). Yeni Öğretim Programlarını İnceleme ve Değerlendirme Raporu, http://ilkogretimonline.org.tr/vol5say1/yenimufredat_rapo ru\%5B1\%5D.pdf adresinden 10.02.2015 tarihinde ulaşılmıştır.

Gömleksiz, M. N. ve Bulut, i. (2007). Yeni hayat bilgisi dersi öğretim programının uygulamadaki etkililiğinin değerlendirilmesi. Milli Eğitim, 173, 67-88.

Grady, M. P. (1998). Qualitative and action research: A Practitioner Handbook. Phi Delta Kappa International Publication: USA.

Gündoğan, A. (2017). 2015 Hayat Bilgisi dersi öğretim programının sosyal beceriler bağlamında incelenmesi. Bayburt Eğitim Fakültesi Dergisi, 12(23), 437-456.

Güneş, T. ve Demir, S. (2007). İlköğretim müfredatındaki Hayat Bilgisi derslerinin, öğrencileri fen öğrenmeye hazırlamadaki etkileri. Hacettepe Üniversitesi Eğitim Fakültesi Dergisi (H. U. Journal of Education) (33), 169-180.

Güven, S.(2010). İlköğretim Hayat Bilgisi dersi ders ve öğrenci çalışma kitaplarının öğretmen görüşlerine göre değerlendirilmesi. Eğitim ve Bilim 35(156).

Karasu Avcı, E. ve Ketenoğlu Kayabaşı, E. Z. (2018). Hayat bilgisi dersi öğretim programlarının amaçlarındaki değerlerin içerik analizi (1936-2018). Journal of Values Education, 16(35).

Kazu, H. ve Aslan, S. (2012). Birleştirilmiş sınıf öğretmenlerinin Hayat Bilgisi dersi öğretim programına yönelik görüşlerinin incelenmesi (nitel bir araştırma). Turkish Studies, 7(2), 693-706.

Küçükkaragöz, H., ve Hartuç, D. A. (2015). İlkokul 2. sınıf Hayat Bilgisi dersinin drama yöntemi ile öğretimine ilişkin bir uygulama önerisi. Yaratıcı Drama Dergisi, 10(1), 1530 .

MEB, (2015). ilkokul Hayat Bilgisi dersi 1, 2 ve 3. sınıflar öğretim programı. https://kirikkale.meb.gov.tr/meb_iys_dosyalar/2015_08/27110255_evrak15595288 4962350592_para1.pdf adresinden 25.10.2015 tarihinde alınmıştır. 
MEB, (2017). Hayat Bilgisi dersi öğretim programı (ilkokul 1, 2 ve 3. sınıflar). http://mufredat.meb.gov.tr/Programlar.aspx adresinden alınmıştır.

MEB, (2018). Hayat Bilgisi dersi öğretim programı(ilkokul 1, 2 ve 3. sınıflar). http://mufredat.meb.gov.tr/Dosyalar/2018122171428547-

HAYAT\%20B\%C4\%BOLG\%C4\%BOS\%C4\%B0\%C3\%96\%C4\%9ERET\%C4\%BOM\%2OPROGRA MI.pdf adresinden 03.08.2018 tarihinde alınmıştır.

Narin, D. (2007). Ilköğretim hayat bilgisi dersi öğretim programının vatandaşlık bilgi, beceri ve değerlerini kazandırmasına ilişkin öğretmen görüşleri. Yayımlanmamış Yüksek lisans tezi. Anadolu Üniversitesi, Eskişehir.

Özçetin, A. (2000). 1998 Illköğretim Hayat Bilgisi Öğretim Programının Öğretmen Görüşleri Açııından Değerlendirilmesi. Yayınlanmamı̧̧ Yüksek Lisans Tezi. OnSekiz Mart Üniversitesi: Çanakkale. Özdemir, M. (1998). Hayat Bilgisi Öğrenme ve Öğretme Etkinlikleri. Ankara: Pegem Yayıncılık.

Özden, Y. (2005). 2004 Yeni hayat bilgisi programının, öğretmen görüşleri esas alınarak değerlendirilmesi (Samsun ili örneği). Eğitimde Yansımalar VIII: Yeni Illköğretim Programlarının Değerlendirilmesi Sempozyumu, Erciyes Üniversitesi Eğitim Fakültesi, Kayseri. 440-445, Tekışık Eğitim Araştırma Vakfı, Ankara.

Öztürk, T. (2015). Öğrencilerin Hayat Bilgisi dersi öğretim programındaki temel becerileri kazanmalarına yönelik öğretmen görüşleri. Eğitim ve Bilim, 4O(181), 271-292.

Öztürk, T. ve Kalafatçı, Ö. (2016). İlkokul Hayat Bilgisi Dersi Öğretim Programının Uygulanabilirliğinin Öğretmen Görüşlerine Göre Değerlendirilmesi. Ihlara Eğitim Araştırmaları Dergisi, 1 (1): 58-74.

Sönmez, V. (1997). Hayat bilgisi öğretimi. Ankara: Anı Yayıncılık

Şahin, M. (2009). Cumhuriyetin kuruluşundan günümüze Türkiye'de Hayat Bilgisi dersi programlarının gelişimi. Journal of International Social Research, 2(8).

Tavşancıl, E. ve Aslan, E. (2001). İ̧erik Analizi ve Uygulama Örnekleri. İstanbul: Epsilon Yayınevi.

Tay, B. ve Baş, M. (2015). 2009 ve 2015 yılı Hayat Bilgisi dersi öğretim programlarının karşılaştııılması. Bayburt Eğitim Fakültesi Dergisi, 10(2). 
Uçuş Güldalı, Ş. (2017). 2009 ve 2017 Hayat bilgisi dersi öğretim programlarının karşılaştırılması, Türk Akademik Yayınlar Dergisi (TAY Journal), 1(1), 76-98.

Uğur, T. (2006). 2005 İlköğretim 1., 2. ve 3. Sınıflar Hayat Bilgisi Dersi Öğretim Programına ilişkin Öğretmen Görüşleri (Uşak i̇li Örneği). Yüksek Lisans Tezi. Afyonkarahisar Kocatepe Üniversitesi Sosyal Bilimler Enstitüsü. Afyonkarahisar

Yaşaroğlu, C. (2013). Hayat Bilgisi dersi kazanımlarının değerler eğitimi açısından incelenmesi. Investigation of Life Science Objectives in Terms of Values Education. Turkish Studies, 8(7), 849-858.

Yıldırım, C. M. (2006). Yeni ilköğretim programının değerlendirilmesi. Ulusal Sınıf Öğretmenliği Kongresi Bildiri Kitabı, Kök Yayıncılık 1(2), 261-268.

Yıldırım, A. ve Şimşek, H. (2006). Sosyal bilimlerde nitel araştırma yöntemleri. Ankara: Seçkin Kitabevi. 